\title{
Demonstration of carcinoembryonic antigen (CEA) expression in normal, chronically inflamed, and malignant pancreatic tissue by immunohistochemistry
}

\author{
WH ALLUM, HJ STOKES, F MACDONALD, JWL FIELDING \\ From the Surgical Immunology Unit, Queen Elizabeth Hospital, Birmingham
}

SUMMARY The expression of carcinoembryonic antigen (CEA) was evaluated by immu- $\omega_{0}$ noperoxidase staining with two anti-CEA monoclonal antibodies in normal, chronically inflamed, $\frac{\sigma}{\sigma}$ and malignant pancreatic tissue. Positive staining was not observed in normal specimens. In pan- $\vec{\circ}$ creatic cancer the expression of CEA was related to the degree of differentiation of the tumour. Positive staining was also observed in chronic pancreatitis.

Carcinoma of the pancreas is often diagnosed by exclusion despite advances in computed tomography and ultrasonography. The early results of tumour localisation with radiolabelled antibodies to tumour associated antigens suggest that this technique may be complementary to the established methods of investigation. ${ }^{12}$ Indeed, it is in conditions such as carcinoma of the pancreas that immunolocalisation may realise its full potential.

The well established association of carcinoembryonic antigen (CEA) with carcinoma of the pancreas suggests that it may be a suitable target for radiolabelled antibodies. Reports have described high values both in the sera ${ }^{34}$ and the pancreatic juice of patients with pancreatic cancer. ${ }^{56}$ Few studies, however have described the tissue distribution of CEA, ${ }^{78}$ which is of great importance if it is to be regarded as a target for immunolocalisation. Studies have also described high values both in the sera and the juice of patients with chronic pancreatitis. ${ }^{5910}$ This apparent lack of specificity of CEA for malignancy has resulted in its limited clinical role as a marker for pancreatic cancer. The development of monoclonal antibodies ${ }^{11}$ has produced agents that have the potential to identify specific tumour antigens or antigenic determinants and so differentiate malignant from benign tissues.

In this study two monoclonal anti-CEA antibodies were evaluated immunohistochemically to determine whether the staining pattern for CEA could differentiate normal, chronically inflamed, and malig-

Accepted for publication 6 February 1986 nant pancreatic tissue and to investigate antigenic ${ }_{-}$ heterogeneity in pancreatic tumours.

\section{Material and methods}

TISSUE SECTIONS

Serial tissue sections $5 \mu \mathrm{m}$ thick were cut from for- $ڤ$ malin fixed paraffin embedded specimens of chronic $\stackrel{\bigcirc}{\varnothing}$ pancreatitis $(n=10)$ and carcinoma of the pancreas $\vec{\overrightarrow{ }}$ $(n=30)$. Most of these specimens were obtained as 3 biopsies at operation and had been stored as paraffin embedded blocks for up to 12 months. The degree of

Table 1 Tissue reactivity of anti-CEA monoclonal antibodies 11-285-14 and 11-359-6

\begin{tabular}{|c|c|c|}
\hline Tissues & $\begin{array}{l}11-285-14 \\
\text { (No positive/No tested) }\end{array}$ & $\begin{array}{l}11-359-6 \\
(\text { No positive/No tested) }\end{array}$ \\
\hline $\begin{array}{l}\text { Skin } \\
\text { Breast } \\
\text { Thyroid } \\
\text { Brain } \\
\text { Lung } \\
\text { Stomach } \\
\text { Colon } \\
\text { Rectum } \\
\text { Appendix } \\
\text { Gall bladder } \\
\text { Liver } \\
\text { Spleen } \\
\text { Lymph node } \\
\text { Tonsil } \\
\text { Lymphocyte } \\
\text { Erythrocyte } \\
\text { Kidney } \\
\text { Prostate } \\
\text { Testis } \\
\text { Uterus }\end{array}$ & $\begin{array}{l}0 / 1 \\
0 / 1 \\
0 / 2 \\
0 / 1 \\
0 / 6 \\
2 / 5 \\
3 / 4 \\
1 / 1 \\
4 / 4 \\
3 / 5 \\
0 / 6 \\
0 / 7 \\
0 / 6 \\
6 / 6 \\
0 / 3 \\
0 / 3 \\
0 / 3 \\
0 / 6 \\
0 / 3 \\
0 / 2\end{array}$ & $\begin{array}{l}0 / 2 \\
\\
1 / 6 \\
1 / 2 \\
3 / 4 \\
1 / 1 \\
4 / 4 \\
2 / 4 \\
0 / 6 \\
1 / 7 \\
0 / 6 \\
6 / 6 \\
0 / 3 \\
0 / 3 \\
0 / 3 \\
0 / 6 \\
0 / 3 \\
0 / 2\end{array}$ \\
\hline $\begin{array}{l}\text { Gastic cancer } \\
\text { Colorectal cancer } \\
\text { Ovarian cancer }\end{array}$ & $\begin{array}{c}208 / 226 \\
49 / 49 \\
4 / 19\end{array}$ & $\begin{array}{r}7 / 10 \\
25 / 25 \\
4 / 19\end{array}$ \\
\hline
\end{tabular}




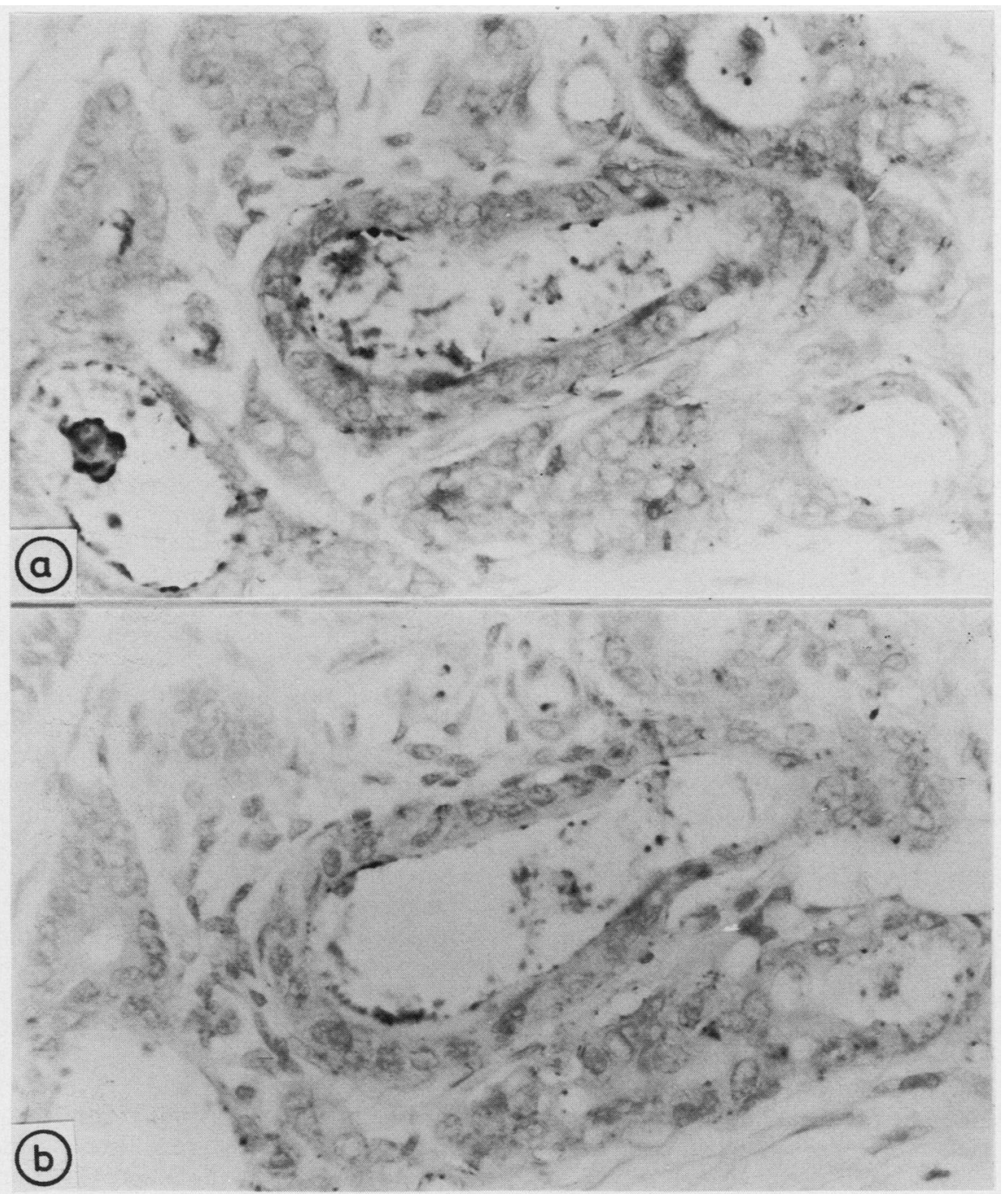

Figure Microphotographs of consecutive sections of specimen of well differentiated pancreatic carcinoma with (a) 11-285-14 and (b) 11-359-6 showing differential staining of tumour cells.

differentiation of the primary tumours was determined by pathological examination of routine haematoxylin and eosin stained sections.

Specimens of normal pancreas were also obtained either at necropsy or from parts of glands removed incidentally at other surgery $(n=10)$.

\section{MONOCLONAL ANTIBODIES}

Monoclonal anti-CEA antibodies 11-285-14 and 11-359-6 were developed by standard methods using CEA extracted from hepatic metastases of a colonic adenocarcinoma. The antibodies have been well characterised and recognise different epitopes on the CEA molecule. ${ }^{12}$ Both belong to the IgGl subclass. In immunohistochemical studies neither 11-285-14 nor 11-359-6 bound to normal tissues except some gastrointestinal tract epithelium and tonsillar epithelium (Table 1). The tonsillar epithelial binding probably reflected the presence of CEA in overlying pharyngeal mucosa rather than in the actual tonsillar tissue. Cross reactivity with non-specific cross reacting antigen (purified from lung) varied, as shown 
Table 2 Proportion of cells staining for CEA in sections of normal pancreas, chronic pancreatitis, and pancreatic adenocarcinoma

\begin{tabular}{|c|c|c|c|c|c|c|}
\hline \multirow{2}{*}{ Total } & & \multicolumn{4}{|c|}{ Percentage staining } & \multirow[t]{2}{*}{ Total } \\
\hline & & 0 & $0-5$ & $5-50$ & $>50$ & \\
\hline $\begin{array}{l}\text { Normal } \\
\text { Pancreas } \\
\text { Chronic } \\
\text { Pancreatitis } \\
\text { Pancreatic } \\
\text { Adenocarcinoma }\end{array}$ & $\begin{array}{l}11-285-14 \\
11-359-6 \\
11-285-14 \\
11-359-6 \\
11-285-14 \\
11-359-6\end{array}$ & $\begin{array}{r}10 \\
10 \\
4 \\
4 \\
7 \\
9\end{array}$ & $\begin{array}{l}2 \\
5 \\
5 \\
7\end{array}$ & $\begin{array}{l}4 \\
1 \\
9 \\
9\end{array}$ & $\begin{array}{l}0 \\
0 \\
9 \\
4\end{array}$ & $\begin{array}{l}10 \\
10 \\
10 \\
10 \\
30 \\
29\end{array}$ \\
\hline
\end{tabular}

by enzyme linked immunosorbent assay, in which 11-285-14 showed little or no activity, whereas 11-359-6 reacted positively. Both antibodies bound to $100 \%$ of the colorectal adenocarcinomas examined $^{13}$ and to $94 \%(11-285-14)$ and $70 \%$ (11-359-6) of gastric cancers. ${ }^{14}$

\section{HISTOCHEMICAL STAINING}

The staining of tissue sections for CEA was carried out using a modified indirect immunoperoxidase technique. ${ }^{15}$ The antibodies at a dilution of $1 / 1000$ (protein concentration, ${ }^{7} 3 \mu \mathrm{g} / \mathrm{ml}$ ) were used as the first antibody and rabbit antimouse antibody conjugated to horseradish peroxidase (Dako) was used as the second antibody at a $1 / 50$ dilution. A 1/1000 dilution of P3-X63-Ag8 ascitic fluid (Bethesda Research Laboratories) was used as a negative control for each batch of sections. In addition, a positive control of primary adenocarcinoma of the colon known to express CEA was included. The tissue sections were examined using light microscopy to determine the number of cells showing a positive reaction. Sections were classified as $(-)$ in which all cells were negative, $(+)$ in which $<5 \%$ of cells were positive, $(++)$ in which $5-50 \%$ were positive, and $(+++)$ in which more than $50 \%$ were positive. This was a subjective assessment made independently by two observers.

\section{Results}

Table 2 shows the pattern of expression of CEA. All of the sections from specimens of normal pancreas were negative for CEA with both antibodies. In addition, normal acini present in sections from malignant or chronically inflamed specimens were similarly negative. Positive staining was present in 23 of $30^{\circ}$. $(77 \%)$ of the specimens of pancreatic ade? nocarcinoma (11-285-14) and in 21 of $29(70 \%)$ (11-359-6). CEA was detected by each antibody on the luminal surface of the neoplastic glands. In mose specimens, however, the cells with positive staining varied according to the antibody used. Thus in one specimen some cells were positive with $11-285-14_{c}^{-}$ and a different population was positive with $11-359-6$ (Figure).

There was also considerable variation between the $\overrightarrow{0}$ different specimens in the number of tumour cells ex-两 pressing CEA. In none of the tumours was there positive staining of all the tumour cells. Staining of mores than $50 \%$ of the cells was observed in nine of 23 긍 $(39 \%)$ of the tumours positive with 11-285-14 and ing four of $20(20 \%)$ with those positive for 11-359-6. Comparison of the percentage of positive cells with the degree of differentiation indicated that those tu- $\frac{0}{3}$ mours with larger numbers of positive cells were the ${ }_{-}$ most differentiated, particularly when stained with 11-285-14 (Table 3). This did not seem to be an abso lute relation, however, as negative staining witho 11-285-14 was also detected in one of the wello differentiated tumours, as was positive staining in oneof the undifferentiated growths. Nevertheless, witho both antibodies negative staining was most common in either anaplastic or poorly differentiated tumours, reflecting the correspondingly low potential for glan $\rightarrow>$ dular formation and CEA expression.

Positive staining with either antibody was observed in six of $10(60 \%)$ specimens of chronic pancreatitis? The actual number of cells that stained, however, was 0

Table 3 Proportion of cells stained for CEA according to degree of tumour differentiation

\begin{tabular}{|c|c|c|c|c|c|c|}
\hline & & \multicolumn{4}{|c|}{ Percentage staining } & \multirow{2}{*}{$\stackrel{\mathbb{C}}{\stackrel{D}{D}}$} \\
\hline & & 0 & $0-5$ & $5-50$ & $>50$ & \\
\hline $\begin{array}{l}\text { Well differentiated }(n=8) \\
\text { Moderately well differentiated } \\
\quad(n=14) \\
\text { Poorly differentiated }(n=8)\end{array}$ & $\begin{array}{l}11-285-14 \\
11-359-6 \\
11-285-14 \\
11-359-6 \\
11-285-14 \\
11-359-6\end{array}$ & $\begin{array}{l}1 \\
0 \\
2 \\
3 \\
4 \\
6\end{array}$ & $\begin{array}{l}1 \\
2 \\
3 \\
3 \\
1 \\
2\end{array}$ & $\begin{array}{l}2 \\
3 \\
4 \\
6 \\
2 \\
0\end{array}$ & $\begin{array}{l}4 \\
3 \\
4 \\
1 \\
1 \\
0\end{array}$ & 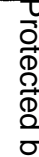 \\
\hline
\end{tabular}


small. As in the malignant specimens the luminal surfaces of the glandular cells were the principal sites of CEA binding. There was also evidence of heterogeneity of antigenic expression, with some cells positive with one antibody and different cells binding the other antibody.

\section{Discussion}

The role of CEA in the management of patients with pancreatic cancer is limited. Studies of early diagnosis have described low serum valves associated with resectable lesions and high serum values associated with invasive metastatic tumours. ${ }^{16}$ Concentrations within normal limits, however, have also been described in patients with advanced disease. ${ }^{17}$ Similarly, CEA values in pancreatic juice have been reported to show a wide variation, irrespective of the presence of pancreatic cancer. ${ }^{5}$ Goldenberg $e t a l^{8}$ suggested that the identification by immunohistochemistry of tumours that express CEA could be used to determine which tumours should be monitored by serial serum CEA estimation. Their study of pancreatic tumours, however, showed positive staining in only three of 11 specimens.

These studies of serum and tissue expression of CEA used polyclonal antisera to CEA. As CEA is physically, chemically, and immunologically a heterogeneous entity, ${ }^{18}$ polyclonal antibodies have failed to identify a truly tumour specific epitope. The development of monoclonal antibodies, ${ }^{11}$ however, may allow more specific subpopulations of CEA to be identified, which would improve the detection of tumour associated CEA. In this study evaluation of two antibodies, which have different binding characteristics for CEA, showed heterogeneity of CEA expression in pancreatic tumours. Both bound to higher percentages of tumour cells than has been previously reported, suggesting that these antibodies have a higher affinity for their respective epitopes of CEA than conventional antisera, or recognise epitopes not identified by the other antibodies.

In a recent study of several different monoclonal anti-CEA and anti-NCA antibodies in panreatic cancer Tsutsumi et al ${ }^{19}$ showed that staining patterns vary in frozen and paraffin embedded tissues. In particular, NCA, or CEA related substances with antigenic determinants common to NCA, were more readily identifiable in frozen sections of normal tissues. In this study we examined only paraffin embedded sections. Although formalin fixation and paraffin embedding may have interfered with the binding of 111-359-6 to NCA in normal pancreatic cells it is more likely that $11-359-6$ recognises a different epitope to that detected by the antibodies reported by Tsutsumi et al.
These results have shown that the epitope recognised by 11-359-6 is less often expressed by pancreatic cancer cells than that recognised by 11-285-14. Nevertheless, neither antibody can be claimed to be specific for CEA in pancreatic cancer, as each reacted positively with cells in $60 \%$ of samples of chronic pancreatitis. This cross reactivity suggests that these antibodies would not be of value in discriminating between chronic pancreatitis and carcinoma in in vivo localisation studies. Such studies would also be limited because of the small number of cells in most tumours that express the antigens.

This study has shown a higher rate of CEA expression in pancreatic cancer cells than has been previously reported. The epitopes of CEA that were detected, however, were also present in chronic pancreatitic cells, indicating that they are not tumour specific. Further monoclonal antibodies to CEA or to other tumour associated antigens, such as pancreatic oncofetal antigen, ${ }^{20}$ should be evaluated in pancreatic cancer to determine whether a tumour specific agent can be identified which differentiates cancer from chronic pancreatitis.

\section{References}

${ }^{1}$ Goldenberg DM, Kim EE, Deland FH, Bennett S, Primus F. Radioimmunodetection of cancer with radioactive antibodies to carcinoembryonic antigen. Cancer Res 1980;40:2984-92.

${ }^{2}$ Mach JP, Carrel S, Forni M, Ritshard J, Donath A, Alberto P. Tumour localisation of radiolabelled antibodies against carcinoembryonic antigen in patients with carcinoma. New Engl J Med 1980;303:5-10.

${ }^{3}$ Laurence DJR, Stevens U, Bettelheim R, et al. Role of plasma CEA in diagnosis of gastrointestinal, mammary, and bronchial carcinoma. Br Med J 1972;iii:605-9.

${ }^{4}$ Zamchek N, Moore TL, Dhar P, Kupchik H. Immunologic diagnosis and prognosis of human digestive tract cancer: carcinoembryonic antigen. New Engl J Med 1972;286:83-6.

${ }^{5}$ Kawiniski H, Sell JE, Pollard HM. Carcinoembryonic antigen and cytology of pancreatic fluid. Gastroenterology 1975;68:923.

${ }^{6}$ Tatsuta M, Yamanioto R, Yamamura H, Okuda S, Tamura H. Cytologic evaluation and carcinoembryonic antigen measurement in aspirated pancreatic material collected by percutaneous fine needle aspiration biopsy under ultrasonic guidance for the diagnosis of pancreatic cancer. Cancer 1983;52:693-8.

${ }^{7}$ Denk H, Tappeiner G, Eckerstorfer R, Holzner JH. Carcinoembryonic antigen in gastrointestinal and extragastrointestinal tumours and its relationship to tumour cell differentiation. Int $J$ Cancer 1972;10:262-72.

${ }^{8}$ Goldenberg DM, Sharkey RM, Primus FJ. Immunocytochemical detection of carcinoembryonic antigen in conventional histopathology specimens. Cancer 1978;42:1546-53.

${ }^{9}$ Deleriche R, Zamchek N, Marion N. Carcinoembryonic antigen in pancreatitis. Cancer 1973;31:328-30.

${ }^{10}$ Lowenstein MS, Zamchek N. Carcinoembryonic antigen levels in benign gastrointestinal disease states. Cancer 1978;42:1412-18.

${ }^{11} \mathrm{Kohler}$ G, Milstein C. Continuous cultures of fused cells secreting antibody of predefined specificity. Nature 1975;256:495-7.

${ }^{12}$ Corvalan JRF, Axton CA, Brandon DR, Smith W, Woodhouse C. Classification of anti-CEA monoclonal antibodies. Protides of Biological Fluids 1983;31:921-4.

${ }^{13}$ Crowson MC, Hockey MS, Newman J, Stokes HJ, Macdonald F, Fielding JWL. An immunocytochemical study of CEA expres- 
sion in colorectal tumours and their metastases. Br J Surg 1984; 71:376.

${ }^{14}$ Hockey MS, Stokes HJ, Thompson H, et al. Carcinoembryonic antigen (CEA) expression and heterogeneity in primary and autologous metastatic gastric tumours demonstrated by a monoclonal antibody. Br J Cancer 1984;49:129-33.

${ }^{15}$ Ford CHJ, Stokes HJ, Newman CE. Carcinoembryonic antigen and prognosis after radical surgery for lung cancer. Immunocytochemical localisation and serum levels. $\mathrm{Br} J$ Cancer 1981;44:145-9.

${ }^{16}$ Zamchek N, Martin EW. Factors controlling the circulating carcinoembryonic antigen levels in pancreatic cancer-some clinical correlations. Cancer 1981;47:1620-7.

${ }^{17}$ Holyoke ED, Douglass HO, Goldrosen MH, Ming Chu T. Tumour markers in pancreatic cancer. Semin Oncol 1979;6: 347-56.
${ }^{18}$ Westwood JH. Carcinoembryonic antigen-its chemistry. In Griffiths K, Neville AM, Pierrepoint CG, eds. Tumour markers-determination and clinical role. Cardiff: Alpha Omega Publishing Limited, 1978:15-28.

${ }^{19}$ Tsutsumi Y, Nagura H, Watanabe K. Immunohistochemical observations of carcinoembryonic antigen (CEA) and CEA-related substances in normal and neoplastic pancreas. Pitfalls and caveats in CEA histochemistry. Am J Clin Pathol 1984;82:535-42.

${ }^{20}$ Banwo O, Vessey J, Hobbs JR. New oncofoetal antigen for human pancreas. Lancet 1974; i:643-5.

Requests for reprints to: Mr WH Allum, Surgical Immu- $\vec{\circ}$ nology Unit, Queen Elizabeth Medical Centre, Edgbaston, Birmingham B15 2TH, England. 